\title{
Need Analysis: Should Preparation in Implementing a Scientific Approach in Elementary Schools?
}

\author{
M. Suswandari*, Siswandari, Sunardi, Gunarhadi \\ Department of Educational Science, Faculty of Teacher Training and Education, Sebelas Maret University, Indonesia
}

Received December 9,2019; Revised December 30,2019; Accepted February 25, 2020

Copyright $\bigcirc 2020$ by authors, all rights reserved. Authors agree that this article remains permanently open access under the terms of the Creative Commons Attribution License 4.0 International License

\begin{abstract}
The purpose of this study is to describe the process of learning by teachers in the implementation of a scientific approach in the 2013 curriculum. This study uses a descriptive qualitative approach. This study uses informant retrieval techniques through purposive sampling. The number of informants in this study was 4 teachers who were in 4 different elementary schools. The schools are Bekonang 01 Elementary School, Kemasan 01 Elementary School, Sonorejo 03 Elementary School, and Sukoharjo 01 Elementary School. The data collection techniques used by researchers include interviews, observation and documentation. The data analysis techniques use data reduction, data display, and conclusions. The results showed that a teacher needs careful preparation through the selection of appropriate learning methods and models in implementing the learning process with a scientific approach in the 2013 curriculum. The success in the learning process requires the creativity and accuracy of the teacher in implementing the scientific approach in learning. Teachers need to prepare well the teaching administration, both syllabus and lesson plans. Planning of teaching administration in the analyzes the needs of students starting from learning objectives, indicators of achievement, basic competencies, materials to methods, learning models, and appropriate evaluation.
\end{abstract}

Keywords Scientific Approach, Curriculum, Elementary School

\section{Introduction}

The curriculum is one of the most important supporting devices in education. Based on the Law of the Republic of Indonesia Number 20 of 2003 concerning the National Education System, it is stated that the curriculum, as a set of plans and arrangements regarding the purpose, content, and material of learning and the methods, is used as guidelines for implementing learning activities to achieve certain educational goals [1].

As the progress of the time progressed, the prevailing curriculum in Indonesia experienced several changes. The curriculum that has been valid in Indonesia is the Competency-Based Curriculum, School-Based Curriculum and Integrated-Based Curriculum. According to E. Mulyasa, Competency-Based Curriculum is a curriculum concept in the development of the ability (competence) of tasks with certain competency standards so that the results can be felt by students in the form of mastery of a set of competencies. School-based curriculum or commonly called KTSP, according to National Education Standards (Article 1 paragraph 15), is an operational curriculum compiled and implemented by each education unit. This means that the preparation of KTSP is carried out by educational units with regard to and based on competency standards and basic competencies developed by the National Education Standards Agency. Thematic or thematic based curriculum, according to NC Teacher, is to integrate the curriculum involving students in the unit building process [2].

Integrated or thematic based learning means learning that combines into one from a variety of different disciplines. These integrated subjects are usually taught in teams, with a set of goals and assessments that are in accordance with the combination of the disciplines that are put together [3], [4], [5]. Thematic or integrated is a combination of several subjects into one theme, namely the subject matter of the discussion or subject matter whose teaching and learning process uses themes by combining the subjects with each other accordingly [4], [6], [7]. Thematic learning can be interpreted as a learning activity by integrating from several subjects into one theme or topic of discussion. Sutirno and Sri Istuti Mamik stated that thematic learning is an attempt to integrate knowledge, skills, values or attitudes of learning, as well as creative thinking using themes [8].

The integrity-based curriculum is a curriculum that was 
raised in 2013 and named 2013 curriculum. The learning process used in 2013 curriculum uses learning with a scientific approach [9]. The application of the scientific approach to learning involves process skills such as observing, classifying, measuring, predicting, explaining, and concluding. These components can be raised in every learning practice, but it is not a learning cycle [4], [6], [7]. In this learning, students are expected to have balanced competencies between attitude, skill, and knowledge that is far more than before, besides the learning outcomes are expected to give birth to students who are productive, creative, innovative, and affective through strengthening integrated domain of attitudes, skills and knowledge.

Hosnan (2014: 34) said that the scientific approach is intended so that students can understand in learning, information obtained to understand a subject matter concept does not only depend on the teacher but can come from anywhere and at any time [10], [11], [12]. Therefore, the teacher should create learning that can direct students to find out from various sources through observation, rather than just being told. This scientific approach is a learning approach that includes five stages, which include the stages of observing, asking questions, gathering information, reasoning and communicating [13]. The 2013 curriculum orientation is the increase and balance between attitude, skills and knowledge [14], [15].

Further explained in the Appendix of the Minister of Education and Culture Regulation number 81A in 2013 that several approaches and learning models that support the implementation of the 2013 curriculum in addition to the scientific approach are discovery/inquiry learning, problem based learning, and project-based learning [16].

The scientific approach can still be used as by a teacher as an alternative approach to activate students in learning [17]. One of the factors that can support the successful use of the Scientific Approach in this integrated thematic learning is teacher professionalism. That is because teachers are the spearhead of the implementation of the 2016 version of the 2013 curriculum, so that teachers are expected to be able to prepare [18].

Research on thematic learning was carried out by Endang (2015: 13), Bernadi (2017: 100), Sari (2015: 82), and Mawardi (2018: 64). The four studies concluded that thematic learning can improve students' social skills. Endang (2015: 13) concluded that thematic learning strategies with scientific approaches can improve students' activities and social skills. This can be seen by the increase in activity and also an increase in the average value of students in each cycle. Similar research was carried out by Bernadi (2017: 100). The results showed that thematic integrative learning with a scientific approach can improve students' social skills. In addition, Mawardi's research (2018: 64) concluded that the scientific approach through the problem-based learning model can provide meaningful experiences so that students can absorb learning more easily. Thematic learning is very important to be applied to develop students' social attitudes and skills. This is relevant to the results of research conducted by Sari (2015: 82) which proves that the ability to communicate of grade $\mathrm{V}$ elementary school students can be improved through learning models that support the learning. Sari (2015: 74) states that the learning model in the scientific approach aims to develop the potential of each student in understanding and deepening the concept of material as a whole because it is integrated into the theme. Research on the use of varied learning models in the scientific approach was conducted by Made Putra (2016: 7) who concluded that the application of a contextual-based scientific approach can improve mastery of Civics knowledge competencies on the theme of my dream for grade $\mathrm{V}$ Kemasan 01 Elementary School [19], [20].

\section{Methods}

This study uses a descriptive qualitative approach. Qualitative approach used in this study is to describe the process of learning by teachers in the implementation of scientific approach the curriculum, 2013. In addition, a descriptive qualitative approach is more effectively used in this study because it can explore research data in depth. The data collection uses depth data retrieval technique informants through purposive sampling. Meanwhile, the informants in this study were elementary school teachers in Sukoharjo Regency. The number of informants in this study was 4 teachers who were in 4 different elementary schools. The elementary school includes Bekonang 01 Elementary School, Kemasan 01 Elementary School, Sonorejo 03 Elementary School, and Sukoharjo 01 Elementary School.

Data collection techniques used by researchers include interviews, observation and documentation. An interview is extracting information on informants through question and answer directly according to research data. Likewise, the data was observed to get the depth of data through phenomena that appeared at the time of the research especially in the implementation of the 2013 curriculum learning process in the classroom. While documentation is a data search through archives, documents, photos and files/portfolios used by the teacher in the learning process in the 2013 curriculum. The entire data that has been collected through interviews, observation and documentation is then processed data in the form of interactive analysis which includes data reduction, data display, and conclusions.

\section{Results and Discussion}

The results showed that the implementation of the 2013 curriculum in the Sukoharjo District Elementary School in the learning process with the scientific approach was carried out through three process activities learning. The 
three stages are planning, implementation and evaluation.

\subsection{First Stage, Planning}

The planning phase is part of the stages of determining learning objectives. Activities for determining learning objectives are carried out by the teacher in the form of preparation of learning devices which include the syllabus and Lesson Plan. Based on observations, interviews, and documentation, the teacher must pay attention to such matters by reviewing the syllabus in advance, preparing materials, setting goals, preparing methods and strategies, preparing and using the media, as well as the planned evaluation of the study, have been implemented if it has been achieved or there must be repetition and follow-up. In reviewing the syllabus according to Mrs. Inggrid (Class V Teacher of Bekonang 01 Elementary School), it is a reference for the preparation of the learning framework, which includes basic competency standards subject matter, learning activity, time spent learning resources and assessment of this syllabus will be very useful as a guide for teachers because they contain overall guidance regarding the purpose and scope of the material to be learned by the students. In addition, it also explains about teaching and learning activities, media, and evaluations that must be used to students in the learning process [21].

Next the device after the syllabus is revealed in the form of lesson plans. Generally, lesson plans in the 2013 curriculum each 1 theme was held for 3 weeks, while in the Week 1 there were 6 meetings, so basically in 1 theme it was held in 18 meetings. Through thematic learning, the teacher prepares learning with an interesting theme and always creates a learning atmosphere to become an educational playground, making learning material more real. The teacher plans to learn in writing and unwritten. Lesson plans made by teachers have included school identity, themes, sub-themes, lesson, basic competence described as indicators [22]. Unwritten planning is that the teacher prepares learning resources, media, and prepares classroom settings, so students are not saturated.

Based on observations that researcher did in teaching and learning activities the teacher uses the Lesson Plan as a reference in carrying out the learning steps. In addition to the results of observations, the researchers also presented the results of interviews with Mr. Purwanto, M.Pd as the five-grade teacher of Bekonang 01 Elementary School, who revealed that:

"Before doing the learning that is done is to prepare the Lesson Plan in advance, the Lesson Plan was obtained from the Teacher Working Group association. So the Lesson Plan used in teaching and learning activities has been discussed together when the association". (Interview on 12 September 2018)

From the results of observations and the results of interviews from various sources above, it can be seen that before doing the learning, teachers in the Sukoharjo
District Elementary School in Sukoharjo District who used the 2013 curriculum first developed a Lesson Plan. The steps of learning activities are carried out in line with what has been listed from the Lesson Plan so that learning runs smoothly [18]. The activity of preparing a learning plan is one of the important tasks in processing student learning. In the perspective of national education policy as outlined in RI Minister of Education Regulation No. 52 of 2008 concerning Process Standards, it is stated that one component in the preparation of the Lesson Plan is the existence of learning objectives in it. Permendiknas RI No. 52 of 2008 concerning Process Standards stated that learning objectives provide instructions for choosing subjects to organize the order of topics, allocate time, guidance in selecting teaching aids and teaching procedures and the provisioned size (standard) to measure student achievement.

The next step at the planning stage is also preparing the learning method. The learning method used by the teacher in teaching must be in accordance with the theme being taught. Based on observations that researchers do, the teacher uses the method of discussion, question and answer, and role-playing, but it is not optimal because the teacher has not raised the activity of students and only certain students are always active [23].

In addition to the results of observations, the researchers also presented the results of interviews with Mrs. Betty S.Pd. as the five-grade teacher of Kemasan 01 Elementary School, which revealed that:

"The learning methods used have not varied so much, although often group work or discussion with peers, question and answer, but there are still many that have not triggered students' interest and activeness" (Interview on date September 28, 2018 )

Thus, implementing the 2013 curriculum at the Sukoharjo District Elementary School in Sukoharjo Regency in carrying out teaching and learning activities, teachers choose a variety and appropriate method. The method used by the teacher varies greatly according to the theme being taught.

\subsection{The Second Stage, Implementation}

After planning in the form of learning devices above, the Teaching and Learning process is continued in the classroom. At the stage of the 2013 curriculum implementation in the Elementary School in Sukoharjo Regency, teachers carried out several activities namely introduction, main activities, and closing.

\subsubsection{Introduction Activities}

The introduction stage, the teacher carries out several steps of activities including the teacher conditions the learning is fun and leads students to understand the material to be taught. Based on observations that the researchers did in the introduction activities, the teacher 
was able to deliver students in fun learning by singing songs or telling stories [20], [21]. In addition, the teacher reviewed yesterday's learning material and then related the material for the day. However, it is not every meeting or every day done by the teacher. Even after greeting, immediately entered the main material of the lesson.

Nevertheless, there are teachers who are also disciplined in introduction activities. This was revealed by Mr. Alim, S.Pd SD as a class V teacher at Sonorejo 03 Elementary School, who said that:

"To start my learning I did a number of activities, including Pray, review the material taught last day, and start learning according to the theme to be taught such as observing pictures and singing songs". (Interview on October 8, 2018).

From the results of observations and the results of interviews from various sources above, it can be seen that the introduction activities carried out at the Sukoharjo District Elementary School in Sukoharjo Regency included teachers arousing students' enthusiasm to take part in learning. In addition, at this stage, the teacher must have the skills to deliver students to the material to be taught.

\subsubsection{Main Activities}

The next stage after the introduction activity is the main activity. In this activity, teaching and learning activities and interactions between students and teachers occur. In learning of 2013 curriculum in Sukoharjo District Elementary School uses a scientific approach is used, which includes five aspects, namely observing, asking, gathering information, associating, and communicating. The following will be explained more clearly.

\subsubsection{Observing}

The step of observing through this problem statement is very good for starting learning because it fosters high curiosity of students about the learning material that students will learn. In observing activities here, students can broadly observe through the activities of seeing, paying attention, listening and reading the material. The teacher facilitates students to make observations and trains them to pay attention to the important things of an object. Competencies developed in observing here are very good because observing can train sincerity, accuracy, and students can search for information that students have not yet gotten.

\subsubsection{Questioning}

From observing activities, according to $\mathrm{Mr}$ Ibnu, the teacher usually asks first and then the students ask the teacher. But it could be the opposite, there are also active students who first ask after the teacher explains the material. This is very good because the students are awakened by their curiosity. Then the teacher can also open broad opportunities for students to ask about what has been seen, listened to, or read. For the step of asking through this stimulus, as the researchers observed the teacher asked questions such as: what is solid? And what kind of solids? Does solid matter melt? In line with the Minister of Education and Culture number $81 \mathrm{~A}$, getting more trained in asking questions will further develop curiosity. These questions form the basis for seeking further and varied information from sources determined by the teacher or determined by students.

\subsubsection{Exploring}

Activities to gather information are usually done through discussion or reasoning to find a lot of data and information. In order to gather the number of information, students can read more books, even use mobile phones to open the internet and search for various data or information on the subject matter. Then Mr Alim, S.Pd SD also said that teachers sometimes facilitate students such as magazines, newspapers or articles, and schools also facilitate students with Wi-Fi networks to make it easier for students to access the internet and of course to find a lot of information.

\subsubsection{Associating}

Association activities aim to develop the ability to think and act scientifically. Information on the results of associating activities is the basis for the next activity, which is processing information to find the linkages of one information with other information, finding patterns of information linkages and even drawing conclusions from patterns found. The data obtained is classified, processed, and found specific relationships [21]. The results of associating activities through data processing and generalization allow students to think critically and students can find out things they have never known before. In the activity of associating through processing and generalization data, students process the information they get from the results of reading and searching from the internet, then they conclude by writing in the document folio that has been provided by the teacher [24].

\subsubsection{Communicating}

The last activity is to communicate it in class and be assessed by the teacher as the learning outcome of the student or group of students. The activity of communicating through verification is a means to check the results of discussions or discoveries made by students who then submit the results in the form of oral, written, sketch drawings, diagrams, or graphs. This activity is carried out so that students are able to communicate their knowledge, skills and implementation, as well as students' creations through presentations, making reports, and/or performance. In the activity of communicating through these verification, students and their groups enthusiastically presented the results of their discussions [5]. Students read out the results of their discussion in front of the class, presenting the results where there were question sessions for other groups or students. Thus, in a presentation, the participants are challenged to provide 
questions to the group of students and the classroom atmosphere becomes more lively because many came out questions that arise from students.

\subsubsection{Closing}

The closing activity of the teacher must review learning on that day so that students understand the material being taught. Based on observations that researchers did in closing learning activities the teacher gave questions to students. Then the teacher assesses the assignment for students whose value is sufficient to carry out enrichment activities and for students whose grades are less doing remedial activities. After enrichment and remedial activities are completed, the teacher and students review the material taught [20], [22].

In addition to the observations, the researchers also presented the results of interviews with class $\mathrm{V}$ students at Sukoharjo 01 Elementary School named Anakel Ramadhani, who stated that in closing activities, the teacher provided enrichment and remedial related assignments given by the teacher and reviewed the material taught. Anakel Ramadhani stated that: "Concluding material, individual tasks, sometimes there are remedies and enrichments". (Interview on October 25, 2018)

The closing activities in the teaching and learning process at the Sukoharjo District Elementary School in Sukoharjo Regency went well. At this stage, the teacher and students conclude the material being taught and follow up in the form of homework. Sometimes in this session, the teacher tries to give a little humour to attract students' interest. In the information delivery activities, the teacher tries to examine more deeply the extent to which students receive.

\subsection{Third Stage, Assessment}

Activities must be carried out to measure the level of understanding of students in teaching and learning activities, namely assessment. The assessment must be carried out by the teacher based on the assessment sheet that has been made. Based on the observation that the researcher did, the teacher did the learning assessment covering three aspects, namely the assessment of attitudes, knowledge and skills [15], [18], Assessment of teacher attitudes uses observations which observe the attitudes of each student when learning takes place. Assessment of teacher knowledge uses written questions to measure the level of student understanding, and assessment of teacher skills assessing the work of students.

In addition to the results of observations, researchers also presented the results of interviews with Mrs. Betty, S.Pd as the five-grade teacher at Kemasan 01 Elementary School, who stated that:

"Using the test of knowledge, both written and oral, As for the assessment of his attitude, I observed each child's behaviour such as during group discussions or others."

\section{(Interview on 28 October 2018)}

Based on the results of observations and interviews from various sources above, it can be concluded that the assessment in the 2013 curriculum at the Sukoharjo District Elementary School in Sukoharjo District carried out three aspects including attitudes, knowledge and skills.

\section{Conclusions}

This study can be concluded that a teacher needs careful preparation through the selection of appropriate learning methods and models in implementing the learning process with scientific instruction in the 2013 curriculum. The learning process is certainly inseparable from the various obstacles and problems faced so as to get success in the learning process creative and accurate teachers are needed in the implementation of various approaches to learning, one of which is the scientific approach that was recently implemented by several schools that have used the 2013 curriculum which is a characteristic of 2013 curriculum. Teachers need to prepare the teaching administration, both syllabus and lesson plans. Planning the teaching administration, analyzes the needs of students starting from learning objectives, indicators of achievement, basic competencies, materials to methods, learning models, and appropriate evaluation. Teachers always keep up with the times and always learn new things. If the teacher can apply the scientific approach appropriately and creatively, this will help the success in the learning process and set goals. However, this study has limitations including data collection in the form of interviews and observations conducted on the number of informants who are limited and cannot fully represent the whole or generalize research subjects in Sukoharjo Regency. Likewise, this research is limited to the elementary school level. Therefore, it is hoped that other researchers can develop a broad range of research or subjects to get the depth of the research data.

\section{REFERENCE}

[1] Suswandari, M. (2018). Selayang Pandang Implikasi Aliran Pendidikan Klasik. Jurnal Komunikasi Pendidikan, 1(1), 33-44.

[2] Suswandari, M. Sosiologi Pendidikan (Pendekatan Teori dan Studi Kasus). Semarang: PT UPGRIS, 2015.

[3] C. Chumdari, S. A. Sri Anitah, B. Budiyono, and N. Nunuk Suryani, "Implementation of Thematic Instructional Model in Elementary School,” Int. J. Educ. Res. Rev., vol. 3, no. 4, pp. 23-31, 2018.

[4] A. N. F. dan M. A. Puspitasari, "An Analysis of Classroom Management Difficulties in Thematic Learning in Sd N 2 Kutosari,” in 3rd National Seminar on Educational 
Innovation (SNIP 2018) SHEs: Conference Series 1 (2) (2018) 55-60 AN, 2018, vol. 1, no. Snip, pp. 55-60.

[5] S. Halidjah, T. Sabri, K. Margiati, and E. Uliyanti, "Thematic Learning Training Based on 2013 Curriculum for Primary School Teachers,” JPKM (Jurnal Pengabdi. Kpd. Masyarakat) UNTAN, vol. 1, no. 3, p. 85, 2018.

[6] L. Nurlaela, M. Samani, I. G. P. Asto, and S. C. Wibawa, "The effect of thematic learning model, learning style, and reading ability on the students' learning outcomes," IOP Conf. Ser. Mater. Sci. Eng., vol. 296, no. 1, 2018.

[7] C. J. Huang, M. C. Liu, S. S. Chu, and C. L. Cheng, “An intelligent learning diagnosis system for Web-based thematic learning platform,” Comput. Educ., vol. 48, no. 4, pp. 658-679, 2007.

[8] I. Z. dan S. A. Amelia Annis Meida, "Types and Functions of Teacher Questions on Thematic Learning of Curriculum 2013 at Primary Schools,” J. Prim. Educ., vol. 9, no. 24, pp. 129-138, 2019.

[9] M. B. Goldwater, R. Bainbridge, and G. L. Murphy, "Learning of role-governed and thematic categories," Acta Psychol. (Amst)., vol. 164, pp. 112-126, 2016.

[10] W. Murtini, "International Journal of Active Learning the Effectiveness of the Scientific Approach to Improve Student Learning Outcomes,” vol. 3, no. 2, pp. 86-91, 2018.

[11] E. Istiawan, Y. U. Anggraito, S. Mulyani, and E. Susilowati, "Journal of Innovative Science Education the Impact of the Implementation of the 2013 Curriculum on Laboratory Management in Wonosobo High School,” vol. 7, no. 2, pp. 367-371, 2018.

[12] D. Rosadi, T. Rahayu, and T. Soenyoto, "Problems with Curriculum 2013 Implementation in Physical Health Education (PJOK) of Junior High School in Sub Rayon 05 Gunungjati District Cirebon Regency,” vol. 8, no. 1, pp. 62-68, 2019.

[13] M. Suswandari, S. Siswandari, S. Sunardi, and G. Gunarhadi, "The Implementation of Problem-Based Learning on Elementary School Students of Sukoharjo,” 2019. ICEL EAI, DOI: 10.4108/eai.23-3-2019.2284940

[14] R. J. Leigh, J. Casson, and D. Ewald, “A Scientific Approach to the Shakespeare Authorship Question,” 2019.

[15] R. A. Sangia and U. N. Surabaya, "National Curriculum 2013: From Literacy to Scientific Approach,” no. November 2014, 2018.

[16] H. Tambunan, "The Effectiveness of the Problem Solving Strategy and the Scientific Approach to Students' Mathematical Capabilities in High Order Thinking Skills," vol. 14, no. 2, pp. 293-302, 2019.

[17] Suswandari, Meidawati \& Siswandari, Siswandari \& Sunardi, Sunardi \& Gunarhadi, Gunarhadi. (2019). The Importance of Power Distance in Students' Social Skills towards Revolution of Industry 4.0 Learning. 10.4108/eai.27-4-2019.2286871.

[18] V. Iasha, "Peningkatan Proses Pembelajaran Tematik Terpadu Menggunakan Pendekatan Scientific di Sekolah Dasar,” vol. 2, no. 1, 2018.

[19] I. O. P. C. Series and M. Science, "The effect of thematic learning model, learning style, and reading ability on the students' learning outcomes The effect of thematic learning model, learning style, and reading ability on the students' learning outcomes,” 2018.

[20] H. Retnawati and S. Munadi, “Teachers' Difficulties in Implementing Thematic Teaching and Learning in Elementary Schools,” no. 2012, 2017.

[21] A. N. and Jumrawarsi, “Teacher' s Problem and Scientific Learning Approach: An Investigation on Teacher' $s$ Problem-Posing Ability Teacher's Problem and Scientific Learning Approach: An Investigation on Teacher' s Problem-Posing Ability,” J. Phys. Conf., 2019.

[22] G. D. P. Maramis and V. R. Palilingan, "Theme network in thematic learning in elementary school,” 2018.

[23] R. Ferguson, T. Coughlan, K. Egelandsdal, M. Gaved, A. Kukulska-hulme, P. Mcandrew, K. Misiejuk, I. J. Ness, E. Scanlon, B. Wasson, and D. Whitelock, Innovating Pedagogy policy makers. 2019.

[24] Suswandari, M. (2019). Cooperative Learning: Strategi Pengembangan Inovasi Pendidikan $\mathrm{Di}$ Indonesia. SCAFFOLDING: Jurnal Pendidikan Islam dan Multikulturalisme, 1(01), 16-24. 